\title{
Disinfectant Treatments That Reduce Transmission of Stagonosporopsis citrulli During Cucurbit Grafting
}

\author{
Anthony P. Keinath ${ }^{\dagger}$ and Virginia B. DuBose, Coastal Research and Education Center, Clemson University, Charleston, SC 29414-5329
}

\begin{abstract}
Gummy stem blight can develop in greenhouses on cucurbit seedlings grown as scions and rootstocks for grafting. When diseased seedlings are cut during grafting, Stagonosporopsis spp., the fungal pathogens causing gummy stem blight, may be transferred to healthy seedlings. The objective of this study was to evaluate efficacy of disinfectant treatments to prevent or reduce transmission during cutting and grafting. A blade contaminated with mycelium and spores from a culture of $S$. citrulli transferred the pathogen to $72 \%, 73 \%$, and $55 \%$ of the second, third, and fourth seedlings, respectively, cut in sequence when $100 \%$ of the first seedlings cut were infected. Kleengro (didecyl dimethyl ammonium chloride), Physan 20 (dimethyl benzyl ammonium chloride), and Virkon S (potassium peroxymonosulfate) were ineffective when sprayed onto watermelon seedlings before or after cutting hypocotyls with a contaminated blade. Dipping a contaminated blade in $0.3 \%$ sodium

hypochlorite, $0.4 \%$ Physan 20 , or $70 \%$ or $95 \%$ ethanol before cutting watermelon hypocotyls significantly $(P=0.01)$ reduced incidence of gummy stem blight compared with water but did not prevent transmission. Soaking a contaminated blade for $3 \mathrm{~s}$ in $95 \%$ ethanol, $30 \mathrm{~s}$ in $0.8 \%$ sodium hypochlorite, or flaming the blade after dipping in $95 \%$ ethanol, prevented transmission. In a grafting experiment, both the watermelon scion and the interspecific hybrid squash rootstock were cut with contaminated or contaminated and treated blades before grafting. Sterilizing a contaminated blade by flaming significantly $(P=0.01)$ reduced incidence of gummy stem when compared with a 1-s dip in ethanol, a 1-s dip in Physan 20, or water. Disease incidences in these treatments were $11 \%, 45 \%, 100 \%$, and $100 \%$, respectively. Using heat, ethanol, or sodium hypochlorite to disinfest cutting tools may reduce transmission of $S$. citrulli during cucurbit grafting.
\end{abstract}

Gummy stem blight of cucurbits is caused by the fungus previously named Didymella bryoniae, which recently was shown to be a complex of three morphologically identical, genetically distinct species: Stagonosporopsis citrulli M.T. Brewer \& J.E. Stewart; S. cucurbitacearum (Fr.) Aveskamp, Gruyter \& Verkley (synonym D. bryoniae (Auersw.) Rehm); and S. caricae (Sydow \& P. Sydow) Aveskamp (Stewart et al. 2015). Stagonosporopsis citrulli is the most widespread of the three species. Gummy stem blight can occur in greenhouses on watermelon (Citrullus lanatus (Thunb.) Matsum. \& Nakai) seedlings grown for use as transplants or scions for grafted watermelons (Boughalleb et al. 2007; Cedeño et al. 2000; Hendricks and Roberts 2015; Keinath 2009, 2011, 2012; Koike 1997; Stevenson et al. 2004). Infected transplants or grafted transplants can be a source of gummy stem blight for field crops (Boughalleb et al. 2007; Keinath 1996). In Tunisia, an arid production area where gummy stem blight does not normally occur, symptoms were first seen at the graft union on grafted plants, while nearby nongrafted plants were symptomless (Boughalleb et al. 2007). Because Stagonosporopsis spp. are seedborne, contaminated seeds produce diseased seedlings, and Stagonosporopsis spp. spread rapidly from these initial foci (Brown et al. 1970; Keinath 1996, 2013b; Lee et al. 1984; Sudisha et al. 2006). Airborne ascospores produced on debris remaining in greenhouses from previous diseased crops are an additional source of inoculum (van Steekelenburg 1983).

Grafting cucurbits may increase the risk of gummy stem blight. During grafting, as the watermelon scion and cucurbit rootstock hypocotyls are cut, the wounded surfaces become very receptive infection courts for $S$. citrulli, regardless of which grafting method is

\section{${ }^{\dagger}$ Corresponding author. E-mail: tknth@clemson.edu}

This material is based upon work supported by National Institute of Food and Agriculture, U.S. Department of Agriculture under project number SC1700446 and award number 2011-51181-30963. Technical Contribution No. 6526 of the Clemson University Experiment Station.

*The $\boldsymbol{e}$-Xtra logo stands for "electronic extra" and indicates that one supplementary figure is published online.

Accepted for publication 29 June 2017.

C 2017 The American Phytopathological Society used (Boughalleb et al. 2007; Davis et al. 2008). Wounding increases the severity of gummy stem blight by enhancing entry of the pathogen into the host and by releasing nutrients from damaged cells that promote conidia germination (Svedelius and Unestam 1978). Gummy stem blight developed in greenhouses on cut cucumber peduncles remaining on plants after the fruit were harvested and on cucumber and melon petioles that were inoculated after leaves were cut and removed (Arny and Rowe 1991; van Steekelenburg 1983; Wako et al. 2000). Stagonosporopsis citrulli infects the two main cucurbit species used as rootstocks for grafting watermelon: bottle gourd (Lagenaria siceraria) and interspecific hybrid squash (Cucurbita moschata $\times$ C. maxima) (Boughalleb et al. 2007; Chiu and Walker 1949; dos Santos et al. 2009; Keinath 2013a). After grafting, plants are held at high relative humidity or under frequent misting for one week to promote healing of the graft union (Hassell et al. 2008). These very moist environmental conditions favor rapid development of gummy stem blight caused by S. citrulli on scions and rootstocks of grafted plants (Arny and Rowe 1991; Keinath 2013a). The fungicides mancozeb and cyprodinil-fludioxonil protected grafted plants from gummy stem blight when they were applied preventatively (Keinath 2013a). However, indiscriminate fungicide use in greenhouses has been linked to development of fungicide resistance in S. citrulli (Hendricks and Roberts 2015; Keinath 2009, 2012; Stevenson et al. 2004).

Serial transmission of Potato virus $Y$ (PVY) onto eight tomato plants cut in succession with a contaminated blade has been demonstrated (Wintermantel 2011). Similarly, Tobacco mosaic virus (TMV), a very stable plant virus, was spread to the twentieth plant cut in sequence using a contaminated blade (Lewandowski et al. 2010). Less work has been done with transmission of fungal pathogens, as the more typical routes of transmission are via direct plant-to-plant contact and dispersal of infested debris or airborne spores. Thus, based on the ability of $S$. citrulli to infect wounded plants, transmission of this pathogen is hypothesized to occur during grafting, but the extent of transmission is unknown.

The disinfectants Virkon S $(21.41 \%$ potassium peroxymonosulfate $+1.5 \%$ sodium chloride) and Physan 20 (10\% dimethyl benzyl ammonium chloride $+10 \%$ dimethyl ethylbenzyl ammonium chloride) have been applied to watermelon seedlings before handling during grafting as general-purpose disinfectants (Hassell et al. 2008; S. Daley, personal communication). Other disinfectants such as trisodium phosphate and quaternary ammonium are used in greenhouse production facilities (Baysal-Gurel et al. 2015; Lewandowski et al. 2010). 
Some of these disinfectants prevent transmission of pathogens during propagation (Copes 2004; Lewandowski et al. 2010; Li et al. 2015; Wintermantel 2011). In one study, $1 \%$ Virkon S and $0.6 \%$ sodium hypochlorite were among the most effective of nine disinfectants tested to prevent or reduce serial transmission of TMV to petunia (Lewandowski et al. 2010). Physan 20 was less effective than $0.5 \%$ sodium hypochlorite for preventing transmission of PVY (Wintermantel 2011). Virkon S, sodium hypochlorite, and KleenGrow applied to the cutting surface prevented transmission of Clavibacter michiganensis subsp. michiganensis during grafting and did not injure tomato (Baysal-Gurel et al. 2010). The effectiveness of disinfectants to reduce or prevent transmission of $S$. citrulli during grafting has not been investigated.

The objectives of this study were to observe grafted plants for phytotoxic effects resulting from disinfectant use, devise a method to simulate transmission of $S$. citrulli via grafting tools, investigate transmission of the pathogen during cutting and grafting, and identify disinfectants and application methods that prevent or reduce infection of cucurbit seedlings by S. citrulli during grafting.

\section{Materials and Methods}

Plant growth, pathogen inoculum and disinfectants. The seedless watermelon cultivars 'Tri-X 313' and 'Fascination' (Syngenta Seeds Inc., Boise, ID) were used as scions. The interspecific hybrid squash 'Strong Tosa' (Syngenta Seeds) and the bottle gourd 'Macis' (Nunhems USA, Parma, ID) were used as rootstocks. Because the three genera have different growth rates, seeding times were adjusted so that plants would be at the growth stages appropriate for grafting when they were used in experiments (Hassell et al. 2008; Keinath 2013a). In general, watermelon, bottle gourd, and interspecific hybrid squash seedlings were 3-weeks, 12-days, and 10-days old, respectively, when used.

Stagonosporopsis citrulli was grown on one-quarter-strength potato dextrose agar for 7 to 10 days at 22 to $24^{\circ} \mathrm{C}$. To induce fruiting body formation, Petri dishes were not sealed and incubated under cool-white fluorescent lights that provided a 16-h photoperiod (Keinath 2013b).

Six common disinfectants used in this study included $0.3 \% \mathrm{vol} / \mathrm{vol}$ sodium hypochlorite, $70 \%$ and $95 \% \mathrm{vol} / \mathrm{vol}$ ethanol, $3 \% \mathrm{vol} / \mathrm{vol}$ hydrogen peroxide, $1 \% \mathrm{wt} / \mathrm{vol}$ Virkon $\mathrm{S}$ (potassium peroxymonosulfate $21.41 \%$ + sodium chloride $1.5 \%$ ), $0.4 \%$ vol/vol KleenGrow (didecyl dimethyl ammonium chloride 7.5\%), and $0.4 \%$ vol/vol Physan 20 (dimethyl benzyl ammonium chloride 10\% + dimethyl ethylbenzyl ammonium chloride 10\%).

Phytotoxicity of disinfectants on grafted plants. Scalpels were dipped for $1 \mathrm{~s}$ in one of the aforementioned six disinfectants or water or flame-sterilized, i.e., blades dipped in 95\% ethanol, passed through a flame to ignite the alcohol, and allowed to cool to ambient temperature $\left(\sim 25^{\circ} \mathrm{C}\right)$. Two scalpels treated the same way were used to cut scion hypocotyls at a $45^{\circ}$ angle below the cotyledons and to cut rootstock seedlings at a $45^{\circ}$ angle through the growing point to remove the meristem and one cotyledon in the one-cotyledon grafting method (Davis et al. 2008; Hassell et al. 2008). Scions and rootstocks were held together with spring-loaded side-grafting clips. Grafted plants were placed in a healing chamber at $99 \%$ relative humidity $(\mathrm{RH})$ for 7 days. After the grafted plants were removed from the healing chamber, the grafting clips were removed from the plants. Two weeks after grafting, the number of grafted plants with living, turgid (not wilted) scions was counted. The experiment was done three times. Tri-X 313 and Fascination were used as scions in each trial (repetition). Strong Tosa seedlings were used as a rootstock in trials one and two, and Macis seedlings were used as a rootstock in trials two and three.

Transmission of $\boldsymbol{S}$. citrulli from diseased seedlings to cut seedlings. Hypocotyls of watermelon Tri-X 313 seedlings were inoculated by piercing them once with a toothpick with mycelium and conidia from a culture of $S$. citrulli W987 with pycnidia. Inoculated seedlings were incubated at $99 \% \mathrm{RH}$ for 3 and 4 days in trials 1 and 2, respectively. Diseased seedlings, $100 \%$ of those inoculated, had a 2- to 3 -cm-long, water-soaked lesion on the hypocotyl but no fruiting bodies. These seedlings were used as the source of inoculum by cutting through a lesion with a flame-sterilized razor blade and then using that blade to cut hypocotyls on 1, 2, 4, or 8 seedlings sequentially. Hypocotyls of Tri-X 313, Fascination, Macis, and Strong Tosa were cut at a $45^{\circ}$ angle below the cotyledons. In each replication of each cultivar, one seedling was cut with a flame-sterilized blade as a noninoculated control. The experimental design was a split-unit, with cultivar as the whole-unit treatment and number of seedlings cut as the subunit treatment. Each treatment combination of cultivar and number of seedlings cut was replicated six times. The experiment was done twice; each repetition will be referred to as a trial. Inoculated seedlings were incubated for 3 days with two replications per humidity chamber. Mean temperature and $\mathrm{RH}$ in the chambers was $26.1^{\circ} \mathrm{C}$ and $93.6 \%$, based on data recorded every 5 min in two chambers (Easylog USB sensors, Lascar Electronics, Erie, PA). After incubation, the number of seedlings with symptoms of browning on the cut surface or water-soaking extending down the hypocotyl was recorded. One 0.5 -cm-long piece taken from the cut end of each hypocotyl was surface disinfested and cultured on semiselective medium to verify infection by recovering $S$. citrulli (Keinath 2013b).

Applying disinfectants to noncontaminated blades and to seedlings. In the first experiment, a single-edge razor blade was dipped in one of six disinfectants or water for $1 \mathrm{~s}$ and used to cut watermelon Tri-X 313 hypocotyls below the cotyledons at a $45^{\circ}$ angle. The cut surfaces of the hypocotyls were then inoculated by touching with a toothpick contaminated with mycelium and conidia from a culture of $S$. citrulli W987 with pycnidia. Inoculated seedlings were incubated for 3 days at a temperature of $26^{\circ} \mathrm{C}$ and $\mathrm{RH}$ of $94 \%$. After incubation, the numbers of seedlings with symptoms of browning or water soaking were recorded. The experiment was done twice.

In the second experiment, three disinfectants, $0.4 \%$ Kleengro, $0.4 \%$ Physan 20 , or $1 \%$ Virkon S, or water were applied directly to watermelon Tri-X 313 seedlings by spraying seedlings with disinfectant solutions in a handheld plastic spray bottle until the liquid began to run down the hypocotyl. Disinfectants were applied before or after the seedlings were cut with a contaminated blade that either was inserted into a culture of $S$. citrulli W986 or dipped into a suspension of $10^{7}$ S. citrulli conidia/ml. Each treatment combination of disinfectant and inoculation was replicated four times, and each replication consisted of eight seedlings. Seedlings cut with a noncontaminated, flame-sterilized blade were included as a control treatment in the second trial. The experimental design was a split-split-unit, with inoculation technique as the whole-unit treatment, time of application as the subunit treatment, and disinfectant as the sub-subunit treatment. Each replication was incubated in a separate humidity chamber for 3 days at a mean temperature of $23.3^{\circ} \mathrm{C}$ and a mean $\mathrm{RH}$ of $99.0 \%$, calculated from data recorded every $5 \mathrm{~min}$ in each chamber. Coolmist atomizing humidifiers (Trion Herrmidifier, Sanford, NC), one per chamber, used in this and subsequent experiments, provided lower temperatures and higher $\mathrm{RH}$ than in the previous experiments. After incubation, the number of seedlings with symptoms of browning on the cut surface or water-soaking extending down the hypocotyl was recorded. Two pieces and one piece in trials one and two, respectively, taken from the cut end of each hypocotyl were cultured as described previously to recover $S$. citrulli.

Applying disinfectants to contaminated blades. A single-edge razor blade contaminated in a culture of $S$. citrulli W986 was dipped into one of six disinfectants or water or flame-sterilized as described previously. Treated blades were then used to cut 1,2 , or 4 Tri-X 13 watermelon hypocotyls below the cotyledons sequentially. One seedling cut with a noncontaminated, flame-sterilized blade served as a noninoculated control for each treatment. Each treatment combination of disinfectant and number of seedlings cut was replicated eight times. The experimental design was a split-unit, with disinfectants as the wholeunit treatment and number of seedlings cut as the subunit treatment. Two replications were placed in each of four humidity chambers for 3 days. After incubation, the numbers of seedlings with symptoms of browning on the cut surface and water-soaking extending down the hypocotyl were recorded. One piece taken from the cut end of each hypocotyl was cultured as described previously on the rating day or 1 day later in trials one and two, respectively, to recover $S$. citrulli. 
Because $0.4 \%$ Physan 20 and $70 \%$ ethanol were the most effective disinfectants, they were tested on grafted plants. Water and a flamesterilized blade served as negative and positive controls, respectively. The experimental design was a randomized complete block with eight replications, and each replication consisted of six grafted seedings. Four-week-old watermelon Tri-X 313 seedlings with one expanded true leaf were used as the scions, and 2-week-old interspecific hybrid squash Strong Tosa seedlings with the tip of the first true leaf visible were used as the rootstocks. Blades were contaminated by inserting them into an agar culture of S. citrulli W986 as described previously. Disinfectant treatments were applied to the contaminated blades before cutting the scion hypocotyls at a $45^{\circ}$ angle below the cotyledons and before cutting the rootstock seedlings to remove one cotyledon and the growing point for the one-cotyledon grafting method. New gloves were used for each disinfectant treatment in trial two. Scion and rootstock were clipped together, and two replications were placed in each of four humidity chambers and held at a mean temperature of $26.4^{\circ} \mathrm{C}$ and a mean $\mathrm{RH}$ of $99.4 \%$ (averaged across the four chambers) for 7 days. Grafted plants were removed from the healing chamber, and the grafting clips were removed. The following day, symptoms of gummy stem blight were recorded as present or absent on the scion and on the rootstock. The number of successful grafts was recorded, i.e., the number of plants with a firm attachment of scion to rootstock. Two $0.5-\mathrm{cm}$ long tissue pieces taken from the cut ends of the scion and from the rootstock were cultured to recover $S$. citrulli as described previously. Recovery from one or two pieces of hypocotyl was considered a positive recovery of the pathogen. The experiment was done twice.

Because dipping contaminated blades in disinfectants for $1 \mathrm{~s}$ was only partially effective with grafted plants, soaking contaminated blades in disinfectants for a longer duration was tested in a final experiment. The experimental design was a split-unit, with disinfectants as the whole-unit treatment and soaking time as the subunit treatment. Each combination of disinfectant treatment and soaking time was replicated eight times, and each replication consisted of three inoculated, treated seedlings and one noninoculated, nontreated control seedling. A blade contaminated in a culture of $S$. citrulli as described previously was dipped into $70 \%$ ethanol, $0.8 \%$ sodium hypochlorite, $0.4 \%$ Physan 20, or water for $3,10,30$, or $90 \mathrm{~s}$, or flamesterilized. Each treated blade was used to cut one watermelon Tri-X 313 hypocotyl below the cotyledons. One seedling cut with a noncontaminated, flame-sterilized blade served as a noninoculated control for each treatment. New gloves were used for each disinfectant treatment. Seedlings were incubated for 3 to 4 days in humidity chambers at a mean temperature of $22.2^{\circ} \mathrm{C}$ and a mean $\mathrm{RH}$ of $95.3 \%$ (averaged across two chambers). The numbers of plants with symptoms on the hypocotyls were recorded 3 to 5 days after inoculation. One piece of tissue taken from the cut end of each hypocotyl was cultured as described previously on the rating day or 1 day later in trials two and one, respectively, to recover $S$. citrulli.

Statistical analysis. Data were analyzed with a mixed-model maximum likelihood analysis (PROC MIXED, SAS version 9.3, SAS Institute Inc., Cary, NC) with treatment as a fixed effect and block as a random effect. Noninoculated control treatments were not included in analyses to reduce problems with nonnormality and inequality of variances among treatments. Before analysis, incidence of symptomatic seedlings and the percentage of the seedlings from which $S$. citrulli was recovered were transformed with arcsine of the square root to correct for nonnormality and inequality of variances. Residuals from analysis of variance were checked for nonnormality and inequality of variance with PROC UNIVARIATE. Back-transformed least-squares means are shown in the tables. Treatment means were compared with Fishers least significant difference test. When data from two trials were combined, trial, treatments, and trial-bytreatment interactions were tested as fixed effects, and block within trial was tested as a random effect. The SLICE option was used to examine interactions.

With some datasets, the proportions of plant parts from which $S$. citrulli was recovered were analyzed with SAS PROC CATMOD for categorical data, which produces a $\chi^{2}$ statistic to evaluate treatment effects. A categorical analysis was used when transformations failed to eliminate inequality of variance and nonnormality in preliminary general linear models analysis of variance, due to the large number of pieces from which S. citrulli was not recovered. Proportions were transformed by calculating the logit, and the linear model parameters were estimated using the maximum likelihood option. In order to get models that included zero values for some categories to converge (i.e., arrive at a unique solution), observed proportions were replaced with a Bayes estimator calculated as $x=(c t+k / r)$ $* n /(n+k)$, where $x=$ the transformed proportion, $c t=$ count of plants with (or without) $S$. citrulli, $r=2$ (for a binary response), $k=$ a constant, which was set equal to $r$, and $n=$ total number of plants (Santner and Duffy 1989). Stepwise model reduction was done to improve the sensitivity of the analysis. The likelihood ratio was used to assess goodness of fit of various models. When factors had a $\chi^{2}$ probability of $\geq 0.10$, they were excluded from the model to increase the population size for the remaining factors, which improved the robustness of the analysis. Contrast statements were written to compare treatments when effects were significant $(P<0.05)$. Proportions were generated using the predict option to back-transform logit values.

\section{Results}

Phytotoxicity of disinfectants on grafted plants. When the bottle gourd Macis and interspecific hybrid squash Strong Tosa were each grafted as a rootstock with the seedless watermelon scions Tri-X 313 and Fascination, the percentage of successful grafts after cutting with a blade dipped in a disinfectant did not differ from the water control for any of the disinfectants tested except Physan 20. Physan 20 reduced the percentage of successful grafts with the rootstock Strong Tosa, but not with Macis, when blades used to cut both scion and rootstock were dipped for $1 \mathrm{~s}$ into disinfectants (rootstock-by-disinfectant interaction, $P=0.02$ ). The percentage of successful grafts with Strong Tosa, regardless of scion cultivar, was less when seedlings were cut with blades dipped in Physan 20 (58\%) than in water (92\%), Virkon S $(91 \%)$, hydrogen peroxide $(86 \%)$, or flamed $(85 \%)$. The percentage of successful grafts with Macis ranged from 78 to $90 \%$ among disinfectant treatments, and no disinfectant treatments differed $(P=0.77)$. No symptoms of injury to scions or rootstocks were observed.

Transmission of $S$. citrulli through cutting contaminated seedlings. In the first trial with diseased watermelon seedlings as the source of inoculum (i.e., seedlings were cut with blades contaminated by cutting water-soaked hypocotyls), one seedling of the cultivar Fascination became diseased out of the 120 that were cut from each cultivar (Fig. 1). In the second trial, 10, 2, 1, and none of the 120 seedlings of Fascination, Tri-X 313, Strong Tosa, and Macis, respectively, became diseased. S. citrulli was recovered from all 14 diseased seedlings but not from any symptomless seedlings (Fig. 1). On some Macis seedlings, the cut surface was brown or water-soaked, but symptoms did not progress down the hypocotyl, and S. citrulli was not recovered from any of these seedlings. All noninoculated seedlings were symptomless, and $S$. citrulli was not recovered from any of them. Because the rate of transmission was so low, a valid analysis of variance could not be done, due to inequality of variances among treatments and nonnormal distribution of residuals. No means for any cultivar were significantly greater than 0 (based on $t$ tests of least-squares means). Overall, $S$. citrulli was transmitted to a mean of $1.4( \pm 0.66) \%$ of the healthy seedlings that were cut using razor blades that were not disinfested after cutting through the water-soaked hypocotyl of a diseased seedling that lacked fruiting bodies.

Data on transmission and recovery of the pathogen were also analyzed from a subsequent experiment in which 1,2 , or 4 watermelon Tri-X 313 seedlings were cut sequentially with a blade contaminated by drawing it through a culture of $S$. citrulli producing conidia. Data for recovery of $S$. citrulli in the water and hydrogen peroxide blade dip treatments were used, because percentage recovery was $\geq 68 \%$ in these two treatments in both trials (Table 1). S. citrulli was transmitted to a mean of $70.3 \pm 5.8$ (standard error), $65.6 \pm 6.0,62.5 \pm 8.7$, and $56.3 \pm 8.9 \%$ of the seedlings cut first, second, third, and fourth in sequence, respectively, with the same contaminated blade not treated between cuts. In experimental units in which the first seedling was diseased (a proportion of 1.0), mean proportions of seedlings that 
became diseased when they were cut second, third, and fourth in sequence after a diseased seedling were $0.72 \pm 0.068,0.73 \pm 0.097$, and $0.55 \pm 0.11$, respectively. Averaged across trials and two disinfectants, recovery of $S$. citrulli was less for the second, third, and fourth seedling than for the first seedling and less for the fourth seedling compared with the third seedling (paired $t$ tests, $P \leq 0.01$ ) (Table 1). Recovery also was less for the third $(0.26 \pm 0.10)$ and fourth $(0.37 \pm 0.11)$ seedlings compared with the second seedling ( $P=0.02$ and $P=0.005$, respectively, $n=19$ seedlings). There were no effects of trial and disinfectant for comparisons between seedlings one and two or between seedlings one and four.

Applying disinfectants to seedlings. When blades were dipped in disinfectants before cutting watermelon hypocotyls that were then inoculated, there were few significant differences among disinfectant treatments or between disinfectant treatments and water for percentage of diseased hypocotyls (Table 2). At least $73 \%$ of the seedlings showed symptoms in both trials in all treatments.

When three disinfectants were sprayed directly onto seedlings before inoculation, symptoms of water-soaking with or without browning of the cut surface were observed on some hypocotyls in both

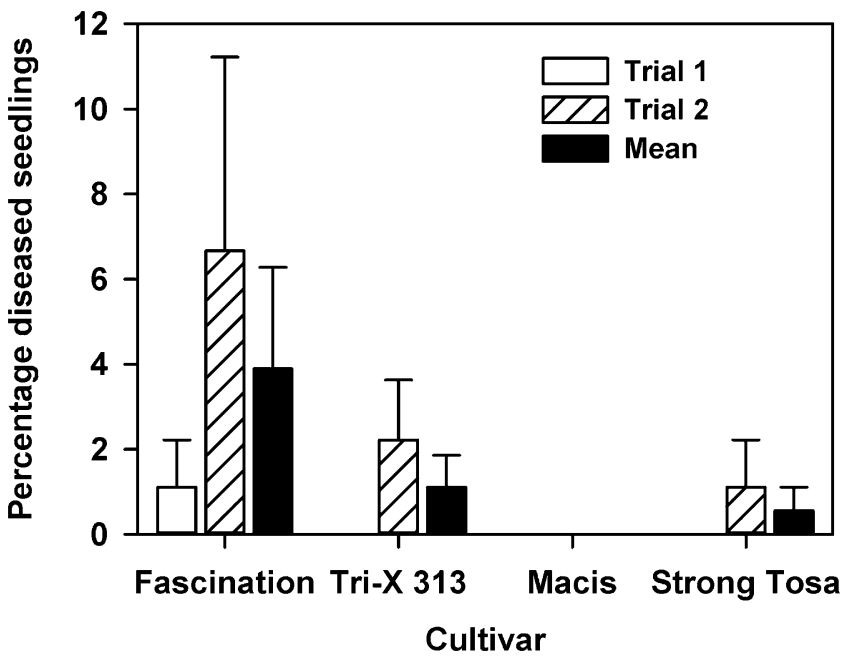

Fig. 1. Proportion of seedlings from which Stagonosporopsis citrulli was recovered after hypocotyls of four cultivars (watermelon 'Fascination' and 'Tri-X 313,' bottle gourd 'Macis,' and interspecific hybrid squash 'Strong Tosa') were cut with a blade contaminated by cutting a water-soaked hypocotyl of an inoculated watermelon 'Tri-X 313' seedling. Each mean was calculated from 120 seedlings. Error bars give one standard error of the mean. repetitions of the experiment, but more hypocotyls had symptoms in trial one $(88.4 \%)$ than in trial two $(38.3 \%)$ (trial main effect significant, $P=0.008$ ) (Table 3). More hypocotyls had symptoms when inoculated with a conidial suspension $(75.2 \%)$ than with mycelium $(55.6 \%)$ (inoculation main effect significant, $P=0.002$ ). The percentage of hypocotyls with symptoms did not differ between disinfectant treatments and water when disinfectants were applied before inoculation, but all three disinfectants reduced the percentage of symptomatic hypocotyls when applied after inoculation (application timingby-disinfectant interaction, $P=0.0005$ ). However, approximately $60 \%$ of the hypocotyls treated after inoculation had symptoms (Table 3). Significantly more hypocotyls had symptoms when water was sprayed after inoculation $(85.8 \%$ ) than before inoculation $(56.4 \%)$, but the percentage of hypocotyls with symptoms did not differ between applications for the three disinfectants. No other interactions were significant. Two of 32 noninoculated hypocotyls had water-soaking symptoms, but $S$. citrulli was not isolated from them.

Although disinfectants applied after inoculation reduced the percentage of hypocotyls with symptoms of gummy stem blight, $S$. citrulli was recovered from $\geq 89 \%$ of all hypocotyls (Table 3 ). There were no differences between disinfectant treatments $(P=0.22)$ or application timings $(P=0.84)$ for percentage recovery. As with symptoms, recovery of the pathogen was higher from hypocotyls

Table 2. Development of gummy stem blight on watermelon 'Tri-X 313' seedlings inoculated with Stagonosporopsis citrulli after disinfectants were applied via blades while cutting hypocotyls

\begin{tabular}{lcc}
\hline & \multicolumn{2}{c}{$\begin{array}{c}\text { Symptomatic } \\
\text { seedlings (\%) }\end{array}$} \\
\cline { 2 - 3 } Disinfectant & Trial 1 $\mathbf{1}^{\mathbf{x}}$ & Trial 2 \\
\hline Water & $90.6 \mathrm{~b}^{\mathrm{y}, \mathrm{z}}$ & $100.0 \mathrm{a}^{\mathrm{z}}$ \\
Hydrogen peroxide 3\% vol/vol & $85.8 \mathrm{~b}^{\mathrm{z}}$ & $100.0 \mathrm{a}^{\mathrm{z}}$ \\
Potassium peroxymonosulfate (Virkon S) & $100.0 \mathrm{a}$ & $99.2 \mathrm{ab}$ \\
$\quad$ 1\% wt/vol & $88.1 \mathrm{~b}^{\mathrm{z}}$ & $100.0 \mathrm{a}^{\mathrm{z}}$ \\
$\begin{array}{l}\text { Ethanol 70\% vol/vol } \\
\text { Didecyl dimethyl ammonium chloride }\end{array}$ & $72.6 \mathrm{~b}^{\mathrm{z}}$ & $99.2 \mathrm{ab}^{\mathrm{z}}$ \\
$\quad$ KleenGrow) 0.4\% vol/vol & $84.7 \mathrm{~b}^{\mathrm{z}}$ & $99.2 \mathrm{ab}^{\mathrm{z}}$ \\
$\begin{array}{l}\text { Sodium hypochlorite 0.3\% vol/vol } \\
\text { Dimethyl benzyl ammonium chloride } \\
\text { (Physan 20) 0.4\% vol/vol }\end{array}$ & $88.5 \mathrm{~b}$ & $90.6 \mathrm{~b}$ \\
\hline
\end{tabular}

$\mathrm{x}$ The trial-by-treatment interaction was significant $(P=0.03)$.

${ }^{y}$ Means shown were back-transformed from the arcsine of the square root, which was used in analysis of variance. Least squares means within columns with the same letter do not differ based on Fisher's least significant difference test, $P \leq 0.015$.

${ }^{\mathrm{z}}$ Means differed between trials, $P<0.01$.

Table 1. Proportion of watermelon 'Tri-X 13' seedlings from which Stagonosporopsis citrulli was recovered after sequential cutting of one to four hypocotyls with the same contaminated blade ${ }^{\mathrm{u}}$

\begin{tabular}{|c|c|c|c|c|c|c|c|c|c|c|c|c|c|c|c|c|}
\hline \multirow[b]{2}{*}{ Factor } & \multicolumn{3}{|c|}{ Seedling 1 versus 2} & \multirow[b]{2}{*}{$N^{x}$} & \multicolumn{2}{|c|}{$\begin{array}{l}\text { Seedling } 1 \\
\text { versus } 3\end{array}$} & \multicolumn{2}{|c|}{$\begin{array}{c}\text { Seedling } 1 \\
\text { versus } 4\end{array}$} & \multirow[b]{2}{*}{$\mathbf{N}^{\mathbf{y}}$} & \multicolumn{2}{|c|}{$\begin{array}{c}\text { Seedling } 2 \\
\text { versus } 3\end{array}$} & \multicolumn{2}{|c|}{$\begin{array}{c}\text { Seedling } 2 \\
\text { versus } 4\end{array}$} & \multicolumn{3}{|c|}{ Seedling 3 versus 4} \\
\hline & $\mathbf{N}$ & $\begin{array}{l}\text { Mean } \\
\text { diff. }^{\mathrm{v}}\end{array}$ & $\operatorname{Pr}>\mathbf{t}^{\mathbf{w}}$ & & $\begin{array}{c}\text { Mean } \\
\text { diff. }\end{array}$ & Pr $>t$ & $\begin{array}{c}\text { Mean } \\
\text { diff. }\end{array}$ & Pr $>t$ & & $\begin{array}{c}\text { Mean } \\
\text { diff. }\end{array}$ & Pr $>t$ & $\begin{array}{c}\text { Mean } \\
\text { diff. }\end{array}$ & Pr $>t$ & $\mathbf{N}$ & $\begin{array}{c}\text { Mean } \\
\text { diff. }\end{array}$ & Pr $>t$ \\
\hline Overall $^{z}$ & 45 & 0.29 & 0.0001 & 22 & 0.27 & 0.01 & 0.45 & 0.0004 & 19 & 0.26 & 0.02 & 0.37 & 0.005 & 16 & 0.38 & 0.009 \\
\hline Trial 1 & 21 & 0.19 & 0.04 & 11 & 0.09 & 0.34 & 0.45 & 0.02 & 11 & 0.09 & 0.34 & 0.36 & 0.04 & 10 & 0.40 & 0.04 \\
\hline Trial 2 & 24 & 0.38 & 0.001 & 11 & 0.45 & 0.02 & 0.45 & 0.02 & 8 & 0.50 & 0.03 & 0.37 & 0.08 & 6 & 0.33 & 0.17 \\
\hline Water & 22 & 0.45 & 0.0004 & 10 & 0.30 & 0.08 & 0.40 & 0.04 & 8 & 0.25 & 0.17 & 0.37 & 0.08 & 7 & 0.29 & 0.17 \\
\hline $\begin{array}{l}\text { Hydrogen peroxide } \\
3 \%\end{array}$ & 23 & 0.13 & 0.08 & 12 & 0.13 & 0.08 & 0.50 & 0.007 & 11 & 0.27 & 0.08 & 0.36 & 0.04 & 9 & 0.44 & 0.03 \\
\hline
\end{tabular}

u Blades were contaminated with S. citrulli by inserting them into an agar plate culture that had pycnidia of the fungus producing conidia.

$\checkmark$ A positive mean difference indicates that the mean proportion of diseased seedlings for the first seedling cut was greater than the mean proportion for the subsequent seedling cut sequentially with the same blade contaminated with S. citrulli.

${ }^{\text {w }}$ Probability that the mean differs from 0 based on a paired $t$ test.

$\mathrm{x}$ Number of comparisons for calculations between seedling 1 and seedlings 3 or 4 .

y Number of comparisons for calculations between seedling 2 and seedlings 3 and 4 .

${ }^{\mathrm{z}}$ The overall calculation included all seedlings from both trials and both disinfectant treatments. 
inoculated with a conidial suspension (91.5\%) than with mycelium $(69.6 \%)$ in trial two, but recovery for both inoculum types was $99.9 \%$ in trial one (trial-by-inoculum interaction, $P=0.0081$ ). No other interactions were significant.

Disinfesting contaminated blades by dipping. Applying certain disinfectants to a blade or flame-sterilizing a blade contaminated with inoculum of $S$. citrulli before the blade was used to cut watermelon hypocotyls reduced the proportion of hypocotyls from which $S$. citrulli was isolated (Table 4). Symptoms of water-soaking were visible on about $30 \%$ of the hypocotyls treated with Virkon S, hydrogen peroxide, or water, but on $<5 \%$ of the hypocotyls treated with the other disinfectants or flaming. However, in a categorical analysis of variance, the proportion of seedlings with symptoms did not differ among treatments. When only the first seedling of the four seedlings cut was considered, sodium hypochlorite, Physan 20, and $70 \%$ and $95 \%$ ethanol reduced recovery compared with water (Table 4). Recovery of $S$. citrulli from hypocotyls treated with Virkon S, hydrogen peroxide, and Kleen Grow did not differ significantly from recovery in the water control treatment $\left(\chi^{2}, P \leq 0.01\right)$. There was no trial-bytreatment interaction $\left(\chi^{2}\right.$ test not significant, $\left.P=0.06\right)$. None of the 144 noninoculated control seedlings showed symptoms, but $S$. citrulli was isolated from one control seedling in trial two. Based on low recovery of S. citrulli, Physan 20 and $70 \%$ ethanol were selected for further testing on grafted seedlings.

When both rootstocks and scions were inoculated by cutting with contaminated and treated blades before grafting, $25.7 \%$ of the 374 rootstocks and scions rated appeared symptomatic in trial one, but in trial 2, 59.8\% had symptoms. Symptoms also were more severe

Table 3. Development of gummy stem blight and recovery of Stagonosporopsis citrulli from watermelon 'Tri-X 313' seedlings sprayed with a disinfectant before or after inoculation with a pathogen-contaminated blade ${ }^{\mathrm{x}}$

\begin{tabular}{|c|c|c|c|c|c|}
\hline Trial & Inoculum & Application timing & Disinfectant & Symptomatic seedlings $(\%)$ & Recovery $(\%)$ \\
\hline 1 & Mycelium & - & - & $82.6 \mathrm{ab}^{\mathrm{y}}$ & $99.9 \mathrm{a}$ \\
\hline 1 & Conidia & - & - & $93.2 \mathrm{a}$ & 99.9 a \\
\hline 2 & Mycelium & - & - & $26.6 \mathrm{c}$ & $69.6 \mathrm{~b}$ \\
\hline 2 & Conidia & - & - & $50.8 \mathrm{~b}$ & $91.5 \mathrm{a}$ \\
\hline- & - & Before & Water & $56.4 \mathrm{a}^{\mathrm{z}}$ & $92.8 \mathrm{a}$ \\
\hline- & - & Before & $\begin{array}{l}\text { Didecyl dimethyl ammonium chloride } \\
\text { (KleenGrow) } 0.4 \% \mathrm{vol} / \mathrm{vol}\end{array}$ & $75.3 \mathrm{a}$ & $97.1 \mathrm{a}$ \\
\hline- & - & Before & $\begin{array}{l}\text { Dimethyl benzyl ammonium chloride } \\
\text { (Physan 20) } 0.4 \% \mathrm{vol} / \mathrm{vol}\end{array}$ & $55.5 \mathrm{a}$ & $93.7 \mathrm{a}$ \\
\hline- & - & Before & $\begin{array}{l}\text { Potassium peroxymonosulfate (Virkon S) } 1 \% \\
\text { wt/vol }\end{array}$ & $68.6 \mathrm{a}$ & $95.3 \mathrm{a}$ \\
\hline- & - & After & Water & $85.8 \mathrm{~A}^{\mathrm{z}}$ & $97.4 \mathrm{a}$ \\
\hline- & - & After & $\begin{array}{l}\text { Didecyl dimethyl ammonium chloride } \\
\text { (KleenGrow) } 0.4 \% \text { vol } / \mathrm{vol}\end{array}$ & $60.2 \mathrm{~B}$ & $93.1 \mathrm{a}$ \\
\hline- & - & After & $\begin{array}{l}\text { Dimethyl benzyl ammonium chloride } \\
\text { (Physan } 20 \text { ) } 0.4 \% \mathrm{vol} / \mathrm{vol}\end{array}$ & $59.4 \mathrm{~B}$ & $89.5 \mathrm{a}$ \\
\hline- & - & After & $\begin{array}{l}\text { Potassium peroxymonosulfate (Virkon S) } 1 \% \\
\text { wt/vol }\end{array}$ & $60.8 \mathrm{~B}$ & $96.1 \mathrm{a}$ \\
\hline
\end{tabular}

“ Blades were contaminated with $S$. citrulli by inserting them into an agar plate culture of the fungus without fruiting bodies ("mycelium") or dipping them into a suspension of $10^{7}$ conidia/ml ("conidia").

y Means shown were back-transformed from the arcsine of the square root, which was used in analysis of variance. The application timing-by-inoculum-disinfectant interaction was not significant $(P=0.94)$. Least squares means for trial-by-inoculum or for timing-by-disinfectant with the same lowercase or uppercase letter do not differ based on Fisher's least significant difference test, $P \leq 0.01$.

${ }^{\mathrm{z}}$ Only the means for water differed between application timings, due to a timing-by-disinfectant interaction, $P=0.0005$.

Table 4. Development of gummy stem blight and recovery of Stagonosporopsis citrulli from watermelon 'Tri-X 13' seedlings inoculated by cutting hypocotyls with a pathogen-contaminated blade dipped in seven disinfectants or water or flame sterilized

\begin{tabular}{|c|c|c|c|c|}
\hline \multirow[b]{2}{*}{ Disinfectant treatment } & \multicolumn{2}{|c|}{$\begin{array}{c}\text { Seedlings with symptoms of gummy } \\
\text { stem blight }(\%)\end{array}$} & \multicolumn{2}{|c|}{ Recovery of S. citrulli $(\%)$} \\
\hline & Observed $^{x}$ & Predicted $^{y}$ & Observed $^{x}$ & Predicted $^{y}$ \\
\hline Water & 31.3 & 43.8 & 79.2 & $54.7 \mathrm{ab}$ \\
\hline Hydrogen peroxide $3 \% \mathrm{vol} / \mathrm{vol}$ & 35.4 & 45.1 & 70.8 & $57.4 \mathrm{a}$ \\
\hline $\begin{array}{l}\text { Potassium peroxymonosulfate (Virkon S) } \\
1 \% \mathrm{wt} / \mathrm{vol}\end{array}$ & 29.2 & 43.1 & 91.7 & $56.0 \mathrm{ab}$ \\
\hline $\begin{array}{l}\text { Didecyl dimethyl ammonium chloride } \\
\text { (KleenGrow) } 0.4 \% \text { vol } / \mathrm{vol}\end{array}$ & 4.2 & 34.7 & 50.0 & $39.0 \mathrm{bc}$ \\
\hline Sodium hypochlorite $0.3 \% \mathrm{vol} / \mathrm{vol}$ & 2.1 & 34.0 & 25.0 & $34.6 \mathrm{c}$ \\
\hline $\begin{array}{l}\text { Dimethyl benzyl ammonium chloride } \\
\text { (Physan 20) } 0.4 \% \mathrm{vol} / \mathrm{vol}\end{array}$ & 0.0 & 33.3 & 20.8 & $32.3 \mathrm{c}$ \\
\hline Ethanol $70 \% \mathrm{vol} / \mathrm{vol}$ & 0.0 & 33.3 & 0.0 & $28.3 \mathrm{c}$ \\
\hline Ethanol $95 \% \mathrm{vol} / \mathrm{vol}$ & 2.1 & 34.0 & 4.2 & $28.3 \mathrm{c}$ \\
\hline Flaming & 2.1 & 34.0 & 0.0 & $26.8 \mathrm{c}$ \\
\hline None, noninoculated ${ }^{\mathrm{z}}$ & 0.0 & not done & 0.7 & not done \\
\hline
\end{tabular}

x Observed percentages of seedlings with symptoms of gummy stem blight or recovery of $S$. citrulli when cultured are means of nontransformed data for 16 seedlings, eight replications in each of two trials.

${ }^{y}$ Predicted percentages of percentages of seedlings with symptoms recovery of S. citrulli when cultured were back-transformed from the logit of proportions in categorical data analysis. A Bayes estimator was used in the analysis in place of the actual proportions to account for sampling zeroes. Means within a column with the same letter are not significantly different based on contrasts of maximum likelihood estimates evaluated with $\chi^{2}$ tests, $P \leq 0.01$.

${ }^{\mathrm{z}}$ Mean of 144 seedlings. The noninoculated treatment was not included in the analysis. 
in trial two than in trial one, as they included not only water-soaking but also cankers and collapse of rootstock hypocotyls and watersoaking, marginal necrotic lesions, and collapse of rootstock cotyledons (Supplementary Fig. S1). Fruiting bodies of S. citrulli were present on several hypocotyls and rootstock cotyledons. In both trials, flaming and $70 \%$ ethanol, but not Physan 20 treatment of the cutting blades, reduced the percentage of grafted plants from which $S$. citrulli was isolated from the scion or the rootstock (Table 5). Recovery was greater with the ethanol treatment than with flaming in trial 1, but these two treatments did not differ in trial two. Consequently, ethanol was more effective in trial two than in trial one $(P=0.001)$. Changing gloves between treatments in trial two may have reduced unintentional pathogen spread from plants in the ineffective treatments to plants treated with ethanol. Results were similar when recovery from both the rootstock and scion on the same plant were analyzed (Table 5). S. citrulli was recovered from both the rootstock and the scion of four to six plants per replication in the water and Physan 20 treatments in trial one and all six plants in trial 2. Results with symptomatic plants were similar to results with recovery, except that the percentage of symptomatic plants did not differ between ethanol and heating in either experiment (Table 5).

In trials one and two, $94.8 \%$ and $90.3 \%$ of the symptomatic rootstocks or scions yielded $S$. citrulli, respectively. The number of rootstocks and scions yielding the pathogen did not differ from the number judged to be symptomatic ( $\chi^{2}$ test, $P>0.05$ ). Of the 27 plants parts rated symptomatic that did not yield the pathogen, 24 came from the flaming or ethanol treatments, 3 came from the Physan 20 treatment, and none came from the water control treatment.

The percentages of successful grafts, i.e., successful attachment of scion to rootstock, varied by trial and treatment (interaction $\mathrm{F}$ test significant, $P=0.01$ ). In trial one, 45 to $51 \%$ of the grafts were successful with the Physan 20 and water treatments, but in trial two, when gummy stem blight was more severe, none of the grafts were successful in these two treatments (Fig. 2). Within trials, the percentage of successful grafts did not differ between plants cut with a flamed blade or a blade treated with $70 \%$ ethanol, and both treatments resulted in a greater percentage of successful grafts than Physan 20 and water $(P \leq 0.0031)$. In trial two, five successfully grafted plants were infected by $S$. citrulli in the flaming treatment but not in the other three treatments. In trial one, however, 81 of the 134 successfully grafted plants were infected; they occurred in all four treatments and in each replication with successful grafts except three replications of the flaming treatment. The percentage of successful grafts was positively correlated with the percentage of healthy plants, i.e., those from which $S$. citrulli was not recovered from scion or rootstock $(r=0.70)$ and negatively correlated with the percentage of plants from which $S$. citrulli was recovered from both parts $(r=-0.66)(P<0.0001)$.

Disinfesting contaminated blades by soaking. Because dipping blades in disinfectants did not prevent pathogen transmission, soaking blades in disinfectants was tested. When blades contaminated with mycelium and spores of $S$. citrulli were soaked for 3 to $90 \mathrm{~s}$ in disinfectant before cutting watermelon hypocotyls, a greater percentage of hypocotyls had symptoms of water-soaking from gummy stem blight in trial one than in trial two. In trial one, $86 \%$ of the hypocotyls in the water control treatment had symptoms, while $<3 \%$ of the hypocotyls treated with disinfectants were symptomatic, and all noninoculated hypocotyls were asymptomatic (Table 6). In trial two, 3 to $7 \%$ of hypocotyls had symptoms in all treatments except flaming, which had no symptoms in either trial. As in other experiments, percentage recovery of $S$. citrulli was much greater than the percentage of seedlings with symptoms in trial one and in the water control in trial two, but percentage recovery was lower than the percentage of seedlings with symptoms in the disinfectant and noninoculated control treatments in trial two. Based on a preliminary analysis of variance, soaking times of $3,10,30$, or $90 \mathrm{~s}$ did not affect symptom development $(P \geq 0.05)$ or recovery $(P \geq 0.13)$ in either trial, and soaking times did not differ from each other (Fig. 3). Means were then calculated across soaking times to reduce inequality of variance due to the large number of noninfected seedlings. In both trials, all four disinfectant treatments reduced recovery of $S$. citrulli compared with the water control (Table 6). In trial one, flaming blades or soaking them in ethanol was more effective than soaking them in $0.8 \%$ sodium hypochlorite or Physan $20(P<0.01)$. In trial two, all four disinfectant treatments were equally effective.

\section{Discussion}

Applying disinfectants to either noncontaminated blades or directly to seedlings were two quick and efficient methods tested in

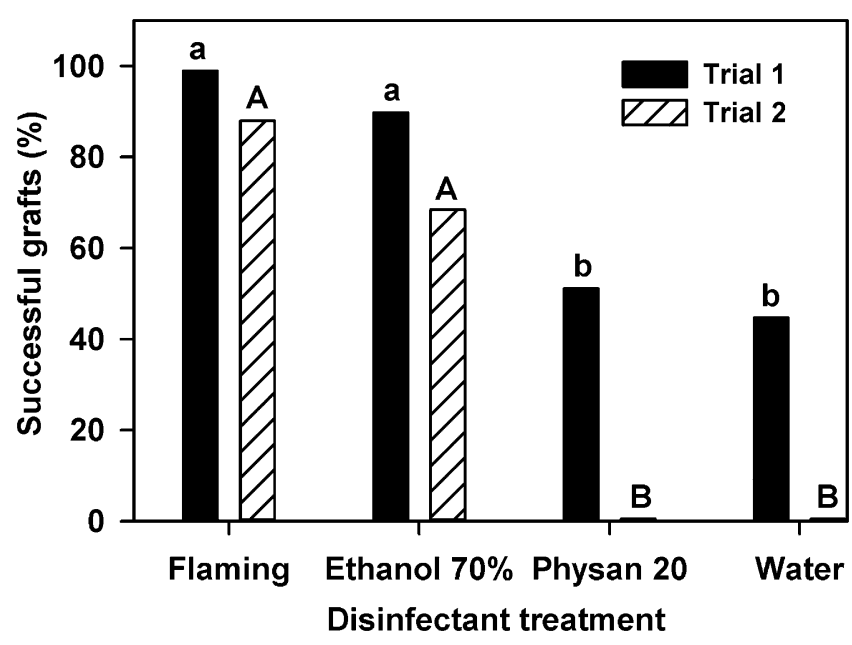

Fig. 2. Percentage of plants with a successful graft after watermelon 'Tri- $X 313$ ' scions and bottle gourd 'Strong Tosa' rootstocks were cut with a blade contaminated with mycelium and conidia of Stagonosporopsis citrulli but treated with one of three disinfectant treatments (flaming, ethanol, or dimethyl benzyl ammonium chloride) compared with a nontreated water control. Means with the same lowercase or uppercase letter do not differ within trials based on $t$ tests $(P \leq 0.003)$. The ethanol and flaming treatments differed between trials $(P<0.0001)$

Table 5. Development of gummy stem blight and recovery of Stagonosporopsis citrulli from grafted watermelon plants that were inoculated by cutting scions and rootstocks with a pathogen-contaminated but flame-heated or disinfectant-dipped blade during grafting

\begin{tabular}{|c|c|c|c|c|}
\hline \multirow[b]{2}{*}{ Disinfectant treatment } & \multirow[b]{2}{*}{ Symptomatic plants (\%) } & \multicolumn{2}{|c|}{$\begin{array}{l}\text { Recovery from scion or } \\
\text { rootstock }(\%)\end{array}$} & \multirow{2}{*}{$\begin{array}{l}\text { Recovery from both scion } \\
\text { and rootstock }(\%)\end{array}$} \\
\hline & & Trial 1 & Trial 2 & \\
\hline$\overline{\text { Flaming }}$ & $5.8 \mathrm{~b}^{\mathrm{y}}$ & $19.1 \mathrm{c}^{\mathrm{y}}$ & $5.0 \mathrm{~b}$ & $1.4 \mathrm{c}^{\mathrm{y}}$ \\
\hline Ethanol $70 \% \mathrm{vol} / \mathrm{vol}$ & $20.8 \mathrm{~b}$ & $68.2 \mathrm{~b}^{\mathrm{z}}$ & $23.4 \mathrm{~b}^{\mathrm{z}}$ & $25.2 \mathrm{~b}$ \\
\hline $\begin{array}{l}\text { Dimethyl benzyl ammonium chloride } \\
\text { (Physan 20) } 0.4 \% \mathrm{vol} / \mathrm{vol}\end{array}$ & $82.7 \mathrm{a}$ & $99.7 \mathrm{a}$ & $100.0 \mathrm{a}$ & $96.8 \mathrm{a}$ \\
\hline Water & $84.6 \mathrm{a}$ & $99.7 \mathrm{a}$ & $100.0 \mathrm{a}$ & $97.5 \mathrm{a}$ \\
\hline Probability for mean comparison tests & $P<0.0001$ & $P \leq 0.0002$ & $P<0.0001$ & $P \leq 0.0003$ \\
\hline
\end{tabular}

${ }^{y}$ Least squares means within columns with the same letter do not differ based on Fisher's least significant difference test. All means shown in the table were backtransformed from the arcsine of the square root, which was used in analysis of variance.

${ }^{\mathrm{z}}$ The only disinfectant means that differed between trials were the means for recovery from scion or rootstock treated with ethanol, $P=0.0012$. 
the grafting process. Applying disinfectants directly to plants is a standard procedure in plant tissue culture (Beyl 2011; Smith 2013). However, no disinfectants consistently prevented development of gummy stem blight when applied via blades before inoculation or when sprayed directly onto seedlings before or after cutting with a contaminated blade. It is likely that the concentration of disinfectant delivered on the blade to the cut hypocotyl surface was too low to inhibit growth of $S$. citrulli. Spraying disinfectants onto seedlings after cutting with a contaminated blade was slightly more effective than spraying the disinfectants before inoculation. Apparently, the disinfectant eradicated the pathogen on less than half of the inoculated cut surfaces. This result provided the impetus to further testing of disinfectants applied directly to a blade after contamination but before cutting.

Infection of the scion, rootstock, or both halves of a grafted watermelon transplant does not necessarily prevent a successful graft union. In the first trial with grafted plants, $60 \%$ of the healed grafted plants were infected with $S$. citrulli. Occurrence of gummy stem blight on successfully grafted plants was reported from Tunisia (Boughalleb et al. 2007). Two reasons may explain why the percentage of symptomless plants that yielded $S$. citrulli was higher in the experiments with grafted plants than in the experiments with watermelon seedlings. With grafted plants, both the scion and the rootstock were inoculated when cut, and the inoculated portions were touching after grafting, so that the inoculum concentration was greater on grafted plants than on nongrafted seedlings. Secondly, grafted plants were incubated in the humidity, i.e., healing, chamber for 7 days, whereas nongrafted seedlings were incubated only 3 days.

S. citrulli was spread to 1 to $2 \%$ of healthy seedlings via a contaminated blade from symptomatic seedings that lacked pathogen signs such as pycnidia or pseudothecia. The water-soaking on the hypocotyls of the source seedlings was very likely due to pectolytic enzymes, which were isolated from melon hypocotyls by Chilosi and Magro (1998). It appears that the pathogen had not colonized the water-soaked hypocotyls, or that the amount of hyphae in the hypocotyls or the amount transferred on blades was not sufficient to infect most inoculated seedlings. However, when a blade was contaminated with mycelium and conidia from a culture or with conidia from a suspension, 70 to $100 \%$ of the cut seedlings became diseased. Although the proportion of diseased seedlings decreased when the same contaminated blade was used to cut up to four seedlings successively, S. citrulli was recovered from $55 \%$ of the seedlings inoculated with the fourth successive cut. Thus, transmission could occur if blades used in grafting became contaminated with inoculum of $S$. citrulli.

In addition to direct contamination of grafted plants, there is potential for secondary spread of $S$. citrulli to additional plants in healing chambers if disinfectant treatments are not used. In a previous study, S. citrulli spread from diseased watermelon seedlings to $10.7 \%$ of the surrounding seedlings in the 200-cell trays typically used to produce transplants, when seedlings were misted on a greenhouse bench (Keinath 1996). Spread of the pathogen among grafted plants is likely to be much greater in the $100 \% \mathrm{RH}$ environment in healing chambers. Thus, $S$. citrulli could spread to at least seven plants in a typical 72-cell tray used for grafted watermelons if a diseased plant were included. If grafted transplants are set at a density of 4,940/ha (or 2000 transplants/acre), there could be 529 diseased transplants per hectare among them.

In previous studies with two viruses, type of disinfectant, exposure time, and pathogen influenced the effectiveness of treatments at preventing transmission (Lewandowski et al. 2010; Wintermantel 2011). Dipping a blade for $2 \mathrm{~s}$ in 5\% sodium hypochlorite was sufficient to prevent any transmission of PVY to tomato, whereas $15 \mathrm{~s}$ was required when $1 \%$ Physan 20 was used (Wintermantel 2011). With TMV and petunia, a 1-min soak was required even with the most effective disinfectants, which included $20 \%$ reconstituted nonfat dry milk, $0.6 \%$ sodium hypochlorite, and $1 \%$ Virkon S (Lewandowski et al. 2010). The longer exposure time for TMV likely was due to the persistent nature of the TMV virion, which is much more resistant to environmental stresses such as dehydration than are conidia, mycelia, or ascospores of Stagonosporopsis. In the current study, the quaternary ammonium disinfectants (KleenGrow or Physan 20) and peroxymonosulfate (Virkon S) were less effective against S. citrulli

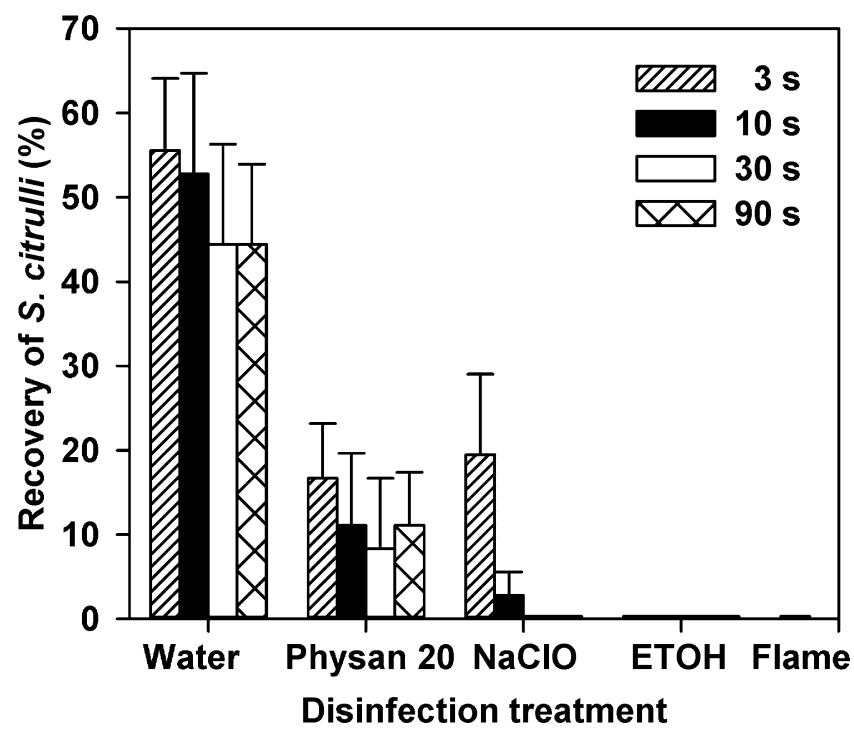

Fig. 3. Percentage of watermelon 'Tri-X 313 ' seedlings from which Stagonosporopsis citrulli was recovered after hypocotyls were cut with a contaminated but disinfected blade. The blade was either soaked for a time duration of $3,10,30$, and $90 \mathrm{~s}$ in a disinfectant ( $70 \%$ ethanol, $0.8 \%$ sodium hypochlorite, or dimethylbenzyl ammonium chloride) or in water or flame-heated. Means shown were calculated from nontransformed data from two experiments.

Table 6. Development of gummy stem blight symptoms and recovery of the pathogen Stagonosporopsis citrulli from watermelon seedlings inoculated by cutting hypocotyls with a pathogen-contaminated but disinfectant-soaked blade ${ }^{\mathrm{x}}$

\begin{tabular}{|c|c|c|c|c|}
\hline \multirow[b]{2}{*}{ Disinfectant treatment } & \multicolumn{2}{|c|}{ Symptoms (\%) } & \multicolumn{2}{|c|}{ Recovery (\%) } \\
\hline & Trial 1 & Trial 2 & Trial 1 & Trial 2 \\
\hline Flaming & $0.0^{\mathrm{x}} \mathrm{b}$ & $0.0 \mathrm{~b}$ & $0.0 \mathrm{c}$ & $0.0 \mathrm{~b}$ \\
\hline Ethanol $70 \% \mathrm{vol} / \mathrm{vol}$ & $0.9 \mathrm{~b}$ & $3.5 \mathrm{a}$ & $0.0 \mathrm{c}$ & $0.0 \mathrm{~b}$ \\
\hline Sodium hypochlorite $0.8 \% \mathrm{vol} / \mathrm{vol}$ & $2.8 \mathrm{~b}$ & $4.6 \mathrm{a}$ & $7.4 b^{y}$ & $0.0 \mathrm{~b}^{\mathrm{y}}$ \\
\hline $\begin{array}{l}\text { Dimethyl benzyl ammonium chloride } \\
\text { (Physan 20) } 0.4 \% \text { vol/vol }\end{array}$ & $1.4 \mathrm{~b}$ & $2.8 \mathrm{ab}$ & $19.4 b^{y}$ & $0.2 b^{y}$ \\
\hline Water & $85.6 \mathrm{a}^{\mathrm{y}}$ & $6.9 \mathrm{a}^{\mathrm{y}}$ & $72.8 \mathrm{a}^{\mathrm{y}}$ & $26.9 \mathrm{a}^{\mathrm{y}}$ \\
\hline None, noninoculated $\mathrm{z}^{\mathrm{z}}$ & 0.0 & 5.9 & 1.0 & 0.0 \\
\hline
\end{tabular}

${ }^{\mathrm{x}}$ Each mean in the table is the average across six replications and four soaking times $(\mathrm{n}=24)$, as there was no disinfectant-by-time interaction, but the trial-bydisinfectant interactions were significant $(P<0.0001$ for symptoms and $P=0.002$ for recovery). Means shown were back-transformed from the arcsine of the square root, which was used in the analysis of variance. Least squares means within columns with the same letter do not differ based on Fisher's least significant difference test, $P<0.01$.

y Means differed between trials, $P<0.01$.

${ }^{\mathrm{z}}$ Means of nontransformed data. The noninoculated treatment was not included in the analysis. 
than the broad-spectrum disinfectants ethanol and sodium hypochlorite. Peroxymonosulfate (Virkon S) also did not kill conidia of Botrytis cinerea, although this fungal pathogen was sensitive to KleenGrow (Baysal-Gurel et al. 2015).

Having one disinfectant effective against multiple pathogen groups would be an advantage in propagation or grafting operations, where more than one type of pathogen may be present. Sodium hypochlorite was effective at preventing transmission of PVY, Tomato mosaic virus, Tobacco mosaic virus, Potato spindle tuber viroid, and C. michiganensis subsp. michiganensis to tomato (Baysal-Gurel et al. 2010; $\mathrm{Li}$ et al. 2015; Wintermantel 2011). A 30-s treatment with sodium hypochlorite also was effective at preventing transmission of $S$. citrulli to cucurbits in the current study. In cucurbit grafting, Acidovorax citrulli, the causal organism of bacterial fruit blotch, is a threat (LaMolinare et al. 2007; Shirakawa et al. 2003). Acidovorax is a gram-negative bacterium, whereas Clavibacter is gram positive. In a study of foodborne bacteria, $10 \%$ sodium hypochlorite was effective in vitro against all 13 gram-negative and two gram-positive bacteria tested (Zheng et al. 2013). Sodium hypochlorite also may be useful against cucurbit viruses that are seedborne and mechanically transmissible, such as Cucumber green mottle mosaic virus, that have been found in grafted watermelon (Boubourakas et al. 2004).

Outputs of grafted plants must be optimized to keep the substantial cost of grafted watermelon transplants, currently estimated to be as much as six times that of nongrafted transplants, as low as possible (Keinath and Hassell 2014). Thus, disinfestation treatments longer than a 1-s dip were originally not considered in this study. However, because a few plants were infected when cut with a contaminated blade dipped in $70 \%$ ethanol or flamed, longer flaming and soaking times may be necessary to maximize the effectiveness of heating and disinfectants. When flaming was used on blades contaminated with TMV, 2 of 21 petunia plants also became infected after being cut with heated blades (Lewandowski et al. 2010). Previous studies on disinfesting blades contaminated with viruses used soaks of at least $2 \mathrm{~s}$ to 1 min (Lewandowski et al. 2010; Wintermantel 2011). Further work may be necessary to determine the optimum disinfestation times for various treatments to prevent all transmission of $S$. citrulli. When disinfectants were mixed with propagules of $B$. cinerea and $C$. michiganensis subsp. michiganensis, 60 -s soaks generally were more effective than soaking for 1 or $30 \mathrm{~s}$ (Baysal-Gurel et al. 2015; Li et al. 2015). In the meantime, a 3-s treatment in 70\% ethanol, a 30-s treatment with $0.8 \%$ sodium hypochlorite, or heating or flaming blades are recommended to prevent transmission of $S$. citrulli during cucurbit grafting.

\section{Acknowledgments}

We thank C. D. Conrad, M. D. Rushton, and G. V. Baccari for technical assistance and Syngenta and Nunhems for donating seed.

\section{Literature Cited}

Arny, C. J., and Rowe, R. C. 1991. Effects of temperature and duration of surface wetness on spore production and infection of cucumbers by Didymella bryoniae. Phytopathology 81:206-209.

Baysal-Gurel, F., Kurowski, C. J., Li, R., Ling, K.-S., and Miller, S. A. 2015. Developing hygiene protocols against mechanically transmitted pathogens in greenhouse tomato production systems. Acta Hortic.: 275-280.

Baysal-Gurel, F., Rajashekara, G., and Miller, S. A. 2010. Effect of disinfectants on transmission of Clavibacter michiganensis subsp. michiganensis during grafting. (Abstr.). Phytopathology 100:S13.

Beyl, C. A. 2011. Getting started with tissue culture-media preparation, sterile technique, and laboratory equipment. Pages 11-26 in: Plant Tissue Culture, Development, and Biotechnology. R. N. Trigiano and D. J. Gray, eds. CRC Press, Boca Raton, FL.

Boubourakas, I. N., Harziloukas, E., Antignus, Y., and Katis, N. I. 2004. Etiology of leaf chlorosis and deterioration of the fruit interior of watermelon plants. J. Phytopathol. 152:580-588.

Boughalleb, N., El Mahjoub, M., Abad-Campos, P., Pérez-Sierra, A., GarcíaJiménez, J., and Armengol, J. 2007. First report of gummy stem blight caused by Didymella bryoniae on grafted watermelon in Tunisia. Plant Dis. 91:468.

Brown, M. E., Howard, E. M., and Knight, B. C. 1970. Seed-borne Mycosphaerella melonis on cucumber. Plant Pathol. 19:198.

Cedeño, L., Carrero, C., and Quintero, K. 2000. Gummy stem blight caused by Didymella bryoniae on watermelon transplants in Mérida, Venezuela. Fitopatol. Venezolana 13:26-29.
Chilosi, G., and Magro, P. 1998. Pectolytic enzymes produced in vitro and during colonization of melon tissues by Didymella bryoniae. Plant Pathol. 47:700-705.

Chiu, W. F., and Walker, J. C. 1949. Physiology and pathogenicity of the cucurbit black-rot fungus. J. Agric. Res. 78:589-615.

Copes, W. E. 2004. Dose curves of disinfestants applied to plant production surfaces to control Botrytis cinerea. Plant Dis. 88:509-515.

Davis, A. R., Perkins-Veazie, P., Sakata, Y., Lopez-Galarza, S., Maroto, J. V., Lee, S. G., Huh, Y. C., Sun, Z., Miguel, A., King, S. K., Cohen, R., and Lee, J. M. 2008. Cucurbit grafting. Crit. Rev. Plant Sci. 27:50-74.

dos Santos, G. R., Ferreira, M. A. S. V., Pessoa-Filho, M. A. C. P., Ferreira, M. E., and Café-Filho, A. C. 2009. Host specificity and genetic diversity of Didymella bryoniae from Cucurbitaceae in Brazil. J. Phytopathol. 157:265-273.

Hassell, R. L., Memmott, F., and Liere, D. G. 2008. Grafting methods for watermelon production. HortScience 4:1677-1679.

Hendricks, K. E., and Roberts, P. D. 2015. Didymella bryoniae isolates from watermelon seedlings in Florida transplant houses and their sensitivity to boscalid. Plant Health Prog. 16:31-33.

Keinath, A. 2011. From native plants in Central Europe to cultivated crops worldwide: The emergence of Didymella bryoniae as a cucurbit pathogen. HortScience 46:532-535.

Keinath, A. P. 1996. Spread of Didymella bryoniae from contaminated watermelon seed and transplants in greenhouse and field environments. Pages 65-72 in: Recent Research Developments in Plant Pathology. Vol. 1. S. G. Pandalai, ed. Research Signpost, Trivandrum, India.

Keinath, A. P. 2009. Sensitivity to azoxystrobin in Didymella bryoniae isolates collected before and after field use of strobilurin fungicides. Pest Manag. Sci. 65:1090-1096.

Keinath, A. P. 2012. Differential sensitivity to boscalid in conidia and ascospores of Didymella bryoniae and frequency of boscalid-insensitive isolates in South Carolina. Plant Dis. 96:228-234.

Keinath, A. P. 2013a. Susceptibility of cucurbit rootstocks to Didymella bryoniae and control of gummy stem blight on grafted watermelon seedlings with fungicides. Plant Dis. 97:1018-1024.

Keinath, A. P. 2013b. Diagnostic guide for gummy stem blight and black rot on cucurbits. Online. Plant Health Prog. doi:10.1094/PHP-2013-1024-01-DG

Keinath, A. P. and Hassell, R. L. 2014. Control of Fusarium wilt of watermelon by grafting onto bottlegourd or interspecific hybrid squash despite colonization of rootstocks by Fusarium. Plant Dis. 98:255-266.

Koike, S. T. 1997. First report of gummy stem blight, caused by Didymella bryoniae, on watermelon transplants in California. Plant Dis. 81:1331.

LaMolinare, B., Isakeit, T., Davis, A., Liu, W., and King, S. 2007. Adding value to grafted watermelon: novel benefits and potential pitfalls. HortScience 42:454.

Lee, D.-H., Mathur, S. B., and Neergaard, P. 1984. Detection and location of seedborne inoculum of Didymella bryoniae and its transmission in seedlings of cucumber and pumpkin. Phytopathol. Z. 109:301-308.

Lewandowski, D. J., Hayes, A. J., and Adkins, S. 2010. Surprising results from a search for effective disinfectants for Tobacco mosaic virus-contaminated tools. Plant Dis. 94:542-550.

Li, R., Baysal-Gurel, F., Abdo, Z., Miller, S. A., and Ling, K.-S. 2015. Evaluation of disinfectants to prevent mechanical transmission of viruses and a viroid in greenhouse tomato production. Virol. J. 12:5. doi:10.1186/s12985-014-0237-5

Santner, T. J., and Duffy, D. E. 1989. The Statistical Analysis of Discrete Data. Springer-Verlag, New York.

Shirakawa, T., Komiya, Y., and Abiko, K. 2003. Secondary transmission of bacterial fruit blotch caused by Acidovorax avenae subsp. citrulli in nursery production of watermelon. Jap. J. Phytopathol. 69:9-14 (In Japanese with English abstract).

Smith, R. H. 2013. Contamination. Pages 53-62 in: Plant Tissue Culture: Techniques and Experiments, 3rd Ed. R. H. Smith, ed. Elsevier, Amsterdam.

Stevenson, K. L., Langston, D. B., Jr., and Seebold, K. W. 2004. Resistance to azoxystrobin in the gummy stem blight pathogen documented in Georgia. Plant Health Prog. doi:10.1094/PHP-2004-1207-01-RS

Stewart, J. E., Turner, A. N., and Brewer, M. T. 2015. Evolutionary history and variation in host range of three Stagonosporopsis species causing gummy stem blight of cucurbits. Fungal Biol. 119:370-382.

Sudisha, J., Niranjana, S. R., Umesha, S., Prakash, H. S., and Shekar Shetty, H. 2006. Transmission of seed-borne infection of muskmelon by Didymella bryoniae and effect of seed treatments on disease incidence and fruit yield. Biol. Control 37:196-205.

Svedelius, G., and Unestam, T. 1978. Experimental factors favouring infection of attached cucumber leaves by Didymella bryoniae. Trans. Br. Mycol. Soc. 71:89-97.

van Steekelenburg, N. A. M. 1983. Epidemiological aspects of Didymella bryoniae, the cause of stem and fruit rot of cucumber. Neth. J. Plant Pathol. 89:75-86.

Wako, T., Ohara, T., Ishiuchi, D., and Kojima, A. 2000. Petiole-mediated inoculation method for seedling test for gummy stem blight (Didymella bryoniae) resistance in melon. (In Japanese with English abstract). Bull. Natl. Res. Inst. Veg., Ornamental Plants Tea 15:71-80.

Wintermantel, W. M. 2011. A comparison of disinfectants to prevent spread of potyviruses in greenhouse tomato production. Online. Plant Health Prog. doi:10.1094/PHP-2011-0221-01-RS

Zheng, L., Bae, Y.-M., Jung, K.-S., Heu, S., and Lee, S.-Y. 2013. Antimicrobial activity of natural antimicrobial substances against spoilage bacteria isolated from fresh produce. Food Control 32:665-672. 